OECD Economics Department Working Papers No. 489

The Fiscal Challenge in Portugal

Stéphanie Guichard,

Willi Leibfritz 
Organisation de Coopération et de Développement Economiques

Organisation for Economic Co-operation and Development

07-Jun-2006

ECONOMICS DEPARTMENT

English - Or. English

THE FISCAL CHALLENGE IN PORTUGAL

ECONOMICS DEPARTMENT WORKING PAPER No. 489

By

Stéphanie Guichard and Willi Leibfritz

All Economics Department Working Papers are available through OECD's Internet web site at www.oecd.org/eco.

JT03210239

Document complet disponible sur OLIS dans son format d'origine

Complete document available on OLIS in its original format 


\section{ABSTRACT/RÉSUMÉ}

\section{The Fiscal challenge in Portugal}

Portugal's fiscal policy has failed to durably reduce the deficit below the Stability and Growth Pact threshold of 3\% of GDP and was submitted to the excessive deficit procedure of the EU Commission for a second time in 2005. The paper describes fiscal developments in Portugal over the past years and explores why earlier attempts of fiscal consolidation have failed. It also examines the new consolidation programme and assesses its chances of success and discusses further necessary steps to ensure consolidation over the longer term. It is argued that reasons for the failures of past consolidation efforts were the pro-cyclical policy during the earlier economic upswing and the reliance on one-off-measures which reduced the sense of urgency and commitment to undertake structural reforms and to address the chronic weak control of public spending. The new consolidation strategy is not relying on one-off measures in a context where Portugal has been granted more time to get its deficit under $3 \%$ of GDP. It includes structural reforms on the spending side that are going in the right direction and, if fully implemented, are likely to succeed in bringing the deficit below 3\% of GDP over the next few years. But consolidation will only be successful if all measures are implemented immediately and forcefully. The consolidation programme needs to be complemented by additional reforms to strengthen expenditure control and in particular to reform the general pension system. On the revenue side, further simplifying the tax system and refraining from revising the tax legislation from one year to the next, as has happened in recent years, would make the tax system easier to manage and would facilitate long-term decisionmaking by economic agents.

JEL Classification: E62, E65, H20, H6.

Keywords: Fiscal policy, Portugal, Budget deficit, Stability programme.

This Working Paper relates to the 2006 OECD Economic Survey of Portugal (www.oecd.org/eco/surveys/portugal)

\section{Le défi budgétaire du Portugal}

La politique budgétaire du Portugal ne lui a pas permis de ramener durablement son déficit sous le seuil de $3 \%$ du produit intérieur brut (PIB) prévu par le Pacte de stabilité et de croissance, si bien que la Commission européenne a déclenché pour la seconde fois la procédure concernant les déficits excessifs contre ce pays en 2005. Nous décrivons dans ce document l'évolution de la situation budgétaire du Portugal ces dernières années, et tentons de cerner les raisons pour lesquelles les précédentes tentatives d'assainissement des finances publiques ont échoué. Nous nous penchons également sur le nouveau programme en la matière et évaluons ses chances de réussite, tout en examinant les mesures complémentaires nécessaires pour assurer l'assainissement des finances publiques à long terme. Nous démontrons que les efforts antérieurs déployés en la matière ont échoué en raison de la politique procyclique menée au cours de la précédente reprise économique, et du recours à des mesures ponctuelles, qui ont atténué le sentiment d'urgence et entamé la détermination nécessaire pour engager des réformes structurelles et remédier aux insuffisances chroniques de la maîtrise des dépenses publiques. La nouvelle stratégie d'assainissement budgétaire ne repose pas sur des mesures ponctuelles, alors que le Portugal s'est vu accorder un délai supplémentaire pour ramener son déficit sous la barre des $3 \%$ du PIB. Elle prévoit au chapitre des dépenses des réformes structurelles qui vont dans la bonne direction et, si elles sont intégralement appliquées, devraient permettre de faire refluer le déficit sous le seuil des $3 \%$ du PIB au cours des prochaines années. Reste que cette stratégie ne sera couronnée de succès que si toutes les mesures prévues sont mises en œuvre immédiatement et énergiquement. Ce programme d'assainissement doit être complété par d'autres réformes destinées à renforcer la maîtrise des dépenses, notamment en réformant le régime général des pensions. Au chapitre des recettes, en simplifiant davantage le système d'imposition et en s'abstenant de réviser la législation fiscale d'une année à l'autre, comme ce fut le cas ces dernières années, les autorités le rendraient plus simple à gérer et faciliteraient les prises de décisions à long terme des agents économiques.

Classification JEL : E62, E65, H20, H6.

Mots clés : politique budgétaire, Portugal, déficit budgétaire, programme de stabilité.

Ce Document de travail se rapporte à l'Étude économique de l'OCDE du Portugal, 2006 (www.oecd.org/eco/etudes/portugal).

Copyright OECD 2006

Application for permission to reproduce or translate all, or part of, this material should be made to: Head of Publications Service, OECD, 2 rue André-Pascal, 75775 Paris Cedex 16, France. 


\section{TABLE OF CONTENTS}

THE FISCAL CHALLENGE IN PORTUGAL

\section{Tables}

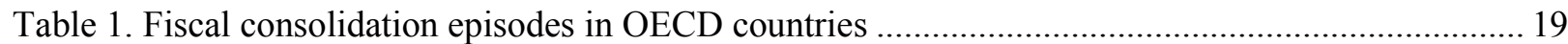

Table 2. Indicators of administrative costs in tax revenue collection and tax arrears ............................. 23

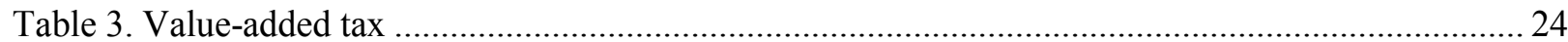

\section{Figures}

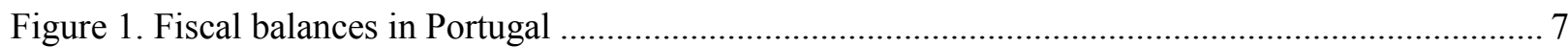

Figure 2. Fiscal balances in Portugal and other euro area countries ................................................. 7

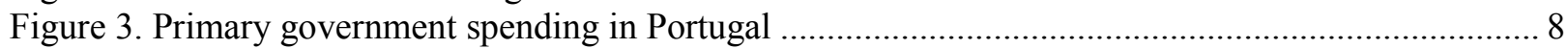

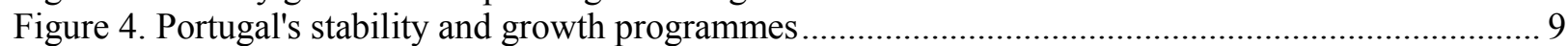

Figure 5. Expected impact of the main consolidation measures ............................................................. 14

\section{Boxes}

Box 1. Portugal's Stability and Growth Programmes and the excessive deficit procedure ...................... 9

Box 2. Measures announced in 2005 to reduce the deficit in the short term......................................... 13

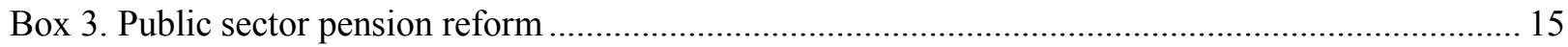

Box 4. Non-Keynesian effects of fiscal consolidation ...................................................................... 17

Box 5. Multi-year expenditure agreements and consolidation: the Netherlands case ............................ 22 
ECO/WKP(2006)17 
ECO/WKP(2006)17

\title{
THE FISCAL CHALLENGE IN PORTUGAL
}

\author{
Stéphanie Guichard and Willi Leibfritz ${ }^{1}$
}

\section{Introduction}

1. Fiscal policy in Portugal has failed to durably reduce the deficit below the Stability and Growth Pact threshold of 3\% of GDP. In 2005 Portugal was again submitted to the excessive deficit procedure of the EU Commission, the second time since joining the European Monetary Union (the first time was in 2002). In response, the government has adopted a consolidation programme designed to bring the deficit down to below $3 \%$ of GDP by 2008 and to $1.5 \%$ of GDP by 2009 .

2. This paper describes fiscal developments in Portugal over the past years and explores why earlier attempts of fiscal consolidation have failed. It also examines the new consolidation programme and assesses its chances of success and discusses further necessary steps to ensure consolidation over the longer term. The main findings are summarized below:

- Various factors contributed to the failure of past consolidation efforts. The consolidation strategy followed between 2002 and 2004 combined a rise in indirect taxes, emergency spending cuts or freezes and one-off measures with more in-depth medium-term measures on the spending side. This strategy was appropriate to deal with the urgency of the situation while addressing Portugal's weak expenditure control with measures that typically take time to show results. However, the reliance on one-off-measures may have reduced the sense of emergency and commitment to undertake the painful structural reforms required. Emergency measures were able to control the wage bill over the short term but other expenditure items, especially pensions, continued to increase strongly. Furthermore, taxes were lowered rapidly once the deficit was below 3\%, even though the underlying situation had not improved. As a result of insufficient consolidation and of weak economic conditions the deficit remained high and increased to $6 \%$ of GDP in 2005, after the decision to stop one-off measures.

- The government that came to office in early 2005 made a strong commitment to significantly reduce the deficit over the coming years. The strategy combines short-term measures to control the wage bill with tax hikes and more in-depth spending reforms. In addition, the control of budget execution is being strengthened. A major difference with the 2002-04 programme is the decision to stop relying on one-off measures in a context where Portugal has been granted more time to get its deficit under 3\% of GDP. The reforms already approved or under preparation are going in the right direction and, if fully implemented, are likely to succeed in bringing the deficit below $3 \%$ of GDP over the next few years. But consolidation will only be successful if all of the announced measures are implemented immediately and forcefully.

1. This paper is based largely on material from the OECD Economic Survey of Portugal published in May 2006 under the authority of the Economic and Development Review Committee (EDRC). The authors would like to thank Bénédicte Larre, Andrew Dean and Val Koromzay for valuable comments on earlier drafts. Special thanks go to Roselyne Jamin for technical assistance and to Nadine Dufour and Lillie Kee for technical preparation. 
- Although fiscal consolidation could have a short-term cost in terms of activity, experience elsewhere shows that this cost can be minimized if consolidation is credible, which implies resolute and consistent action that delivers solid results. Therefore it is important that the authorities remain committed to achieving the projected fiscal consolidation without slippage and that the planned structural reforms on the spending side are launched quickly and implemented forcefully. Ongoing steps to improve statistical information on spending at all levels should continue. Consideration should also be given to improving the fiscal framework drawing from successful experiences in other OECD countries, in particular adopting medium-term expenditure ceilings that are consistent with the desired consolidation path and strengthening the role of independent economic advisors councils in the preparation of the budgets and the assessment of final outcomes.

- The consolidation programme nevertheless needs to be complemented by additional reforms to strengthen expenditure control. A key pending reform is the reform of the general pension system to ensure its viability. The system is under strong pressures arising not only from the ageing population but also from its maturation and the high replacement rates granted to retirees. Updated official simulations show that the system will likely be in deficit by 2007 , and could be financed thereafter for only 7 years by the pension trust fund. Therefore action is urgent. Radical changes should be envisaged, such as adjusting replacement rates and/or the retirement age for changes in life expectancy and limiting the costs of transition by a relatively rapid phasing-in.

- On the revenue side, there is no room to lower taxes before the public finances have been put on a sustainable path. Nevertheless, there is ample room for further simplification of the tax regime, which is as important for competitiveness as lowering tax rates and can help to further improve the efficiency of tax collection. Furthermore, refraining from revising the tax legislation from one year to the next, as has happened in recent years, would make the tax system easier to manage and would facilitate long-term decision-making by economic agents.

\section{Past deficit trends}

3. Over the past two decades Portugal's fiscal policy has had a bumpy ride (Figure 1). High deficits (often above 5\% of GDP) were recorded till the mid-1990s. Then, the general government deficit was reduced progressively to below 3\% in 1999-2000, helped by the fall in interest rates in the context of the euro accession process and by high tax revenue spurred by strong economic growth. The consolidation process was, however, temporarily interrupted in 2001 when the deficit increased to around $4 \frac{1}{4}$ per cent of GDP, but resumed between 2002 and 2004. During that period, the deficit was contained at 3\% of GDP or slightly below. However, the underlying situation remained weak: the consolidation programme included one-off measures amounting to $2 \%$ of GDP a year on average, while expenditure was still growing fast. In 2005 , when reliance on one-off revenue measures was abandoned and both structural and conjunctural pressures on spending increased, the deficit rose to a new peak of close to $6 \%$.

4. The pronounced weakness of the economy during the past years has put pressure on Portugal's public finances and made the task to consolidate the budget more difficult. The fiscal deficit had not been cut sufficiently during the previous boom, amounting to almost 3\% of GDP (the Maastricht threshold) when the boom ended in 2000 , which left no room for letting automatic stabilisers operate effectively during the subsequent downturn. ${ }^{2}$ This pro-cyclical behaviour of fiscal policy can be seen from the different developments of the primary balance and the cyclically-adjusted primary balance in the second half of the 1990s and after 2001.

2. According to OECD estimates, during 2003-2005 Portugal's output gap was on average $23 / 4$ per cent and much larger than the euro area average of above $1 \%$. 
Figure 1. Fiscal balances in Portugal As per cent of GDP

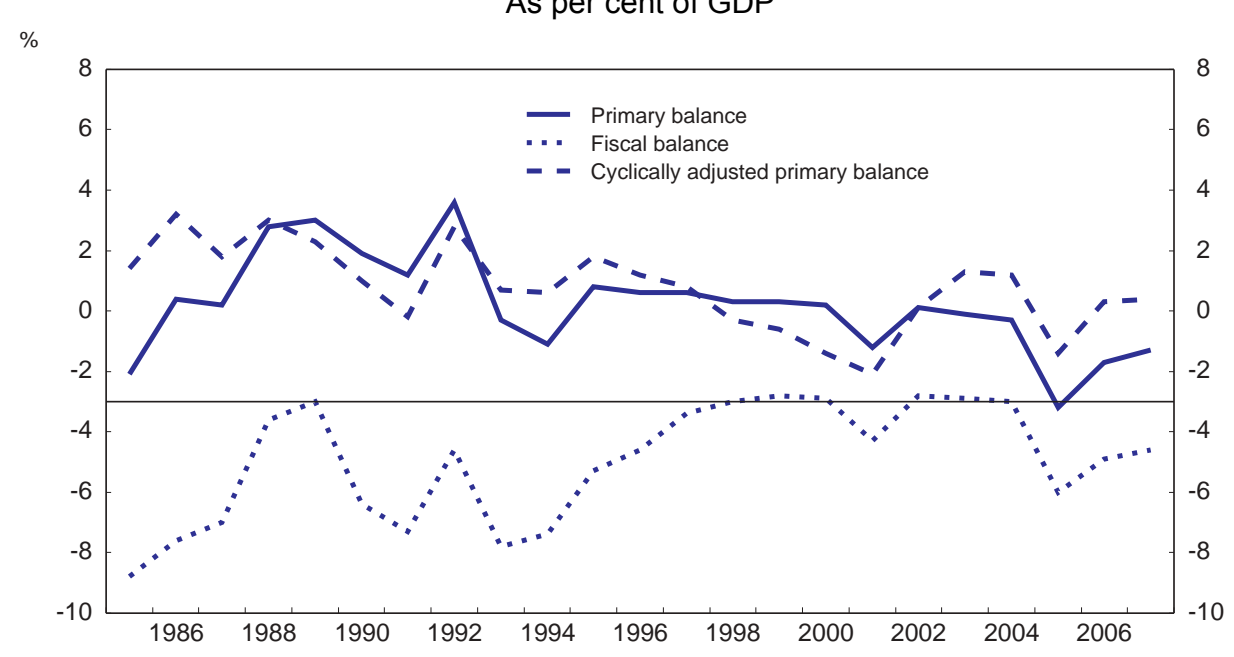

Source: OECD, Economic Outlook No. 78.

5. In the fall of 2005, for the second time since 2002, Portugal has been put under the European excessive fiscal deficit procedure (Box 1). Portugal was not alone in breaching EU fiscal rules, but its performance regarding fiscal control has long been worse than that of other euro area countries (except for Greece) (Figure 2).

Figure 2. Fiscal balances in Portugal and other euro area countries ${ }^{1}$ As per cent of GDP

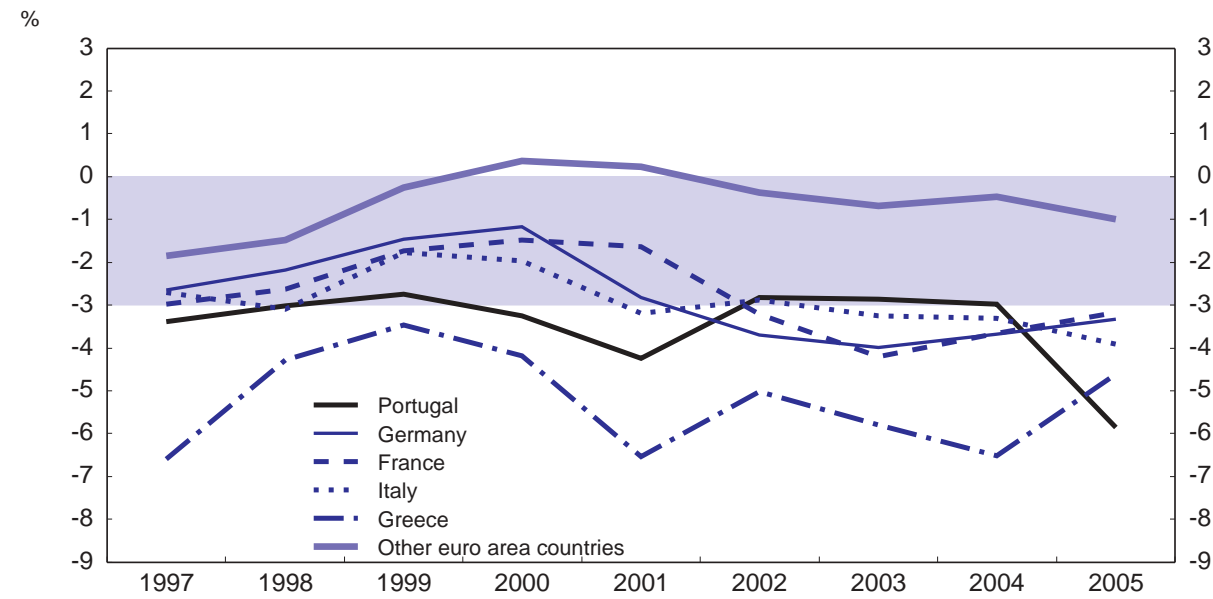

1. Excluding UMTS licence proceeds.

Source: OECD, Economic Outlook No 78; Analytical database.

6. Cyclical factors can, however, only explain part of Portugal's poor fiscal position. As stressed in the 2003 OECD Economic Survey of Portugal, the roots of the persistent weakness of public finances lie on the spending side. Primary spending has been on an upward trend over the past 15 years. Cyclicallyadjusted primary spending increased sharply and with only a few interruptions between the end of the 1980s and the beginning of the 2000s (Figure 3). The windfall gains from lower interest rates in the 1990s (reducing government net interest payments by around 5 $\frac{1}{2}$ percentage points of GDP) were spent to 
finance higher primary current expenditure instead of restoring fiscal soundness. In particular, spending was pro-cyclical during the periods of positive output gaps, as in 1989-92 and 1997-2000. Indeed, if the surplus of around 3\% in the cyclically-adjusted primary balance recorded in the late 1980 s had been maintained, the overall budget would now be close to balance. Instead, spending continued to increase, and revenues had to be raised to prevent even larger fiscal imbalances. The two items that account for the largest part of the upward trend in public expenditure are compensation of public employees and social transfers. Compensation of employees (which includes both the wage bill that increased until 2002 and transfers and contribution to the civil servant social security system) increased by $3.1 \%$ of GDP over the past 15 years and social benefits to households by $5.5 \%$ of GDP. When breaking down the increase in government expenditure by functional classification, social protection shows the largest increase over that period (5.7\% of GDP, mainly on old age pensions) followed by health (3.1\% of GDP) and education (1.8\% of GDP). In addition, the quality of public services has not increased in line with spending, pointing to some efficiency issues. This is the case in particular in education (see Guichard (2006), and in health care (see Guichard, 2004).

7. In 2005, the cyclically-adjusted deficit in the primary balance amounted to $1 \frac{1}{2}$ per cent of GDP and if prolonged, it would lead to a continuous increase in the debt-to-GDP ratio and would further damage private sector confidence. Portugal also runs the risk that long-term interest rates, which are currently low internationally, increase again and/or that continued high deficits lead to a risk premium for government bonds, which would further aggravate its fiscal situation. ${ }^{3}$ On the other hand, sound public finances would support growth in the long term by allowing automatic stabilisers to operate fully during downturns, putting the public sector in a better position to respond to the long-term development needs of Portugal and contributing to a friendlier business environment by improving the efficiency of public services.

Figure 3. Primary government spending in Portugal

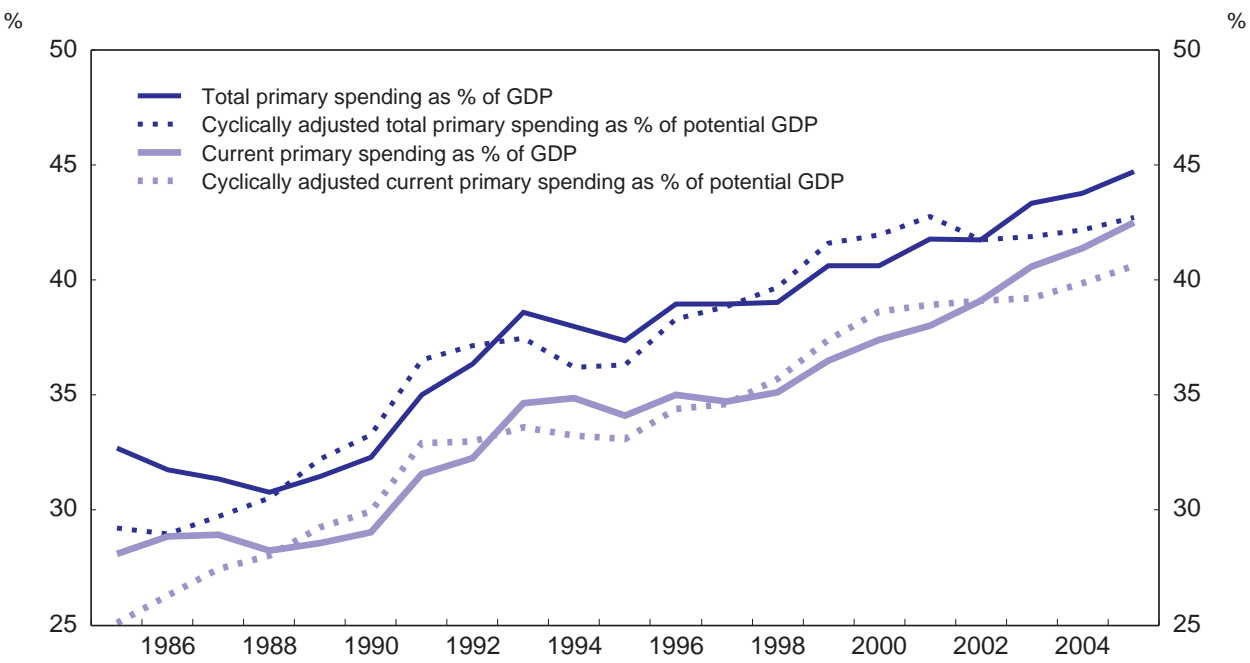

Source: OECD, Economic Outlook No. 78.

3. The December 2005 update of the Stability Programmes presents some simulation of the impact of higher (short and long term) rates on the macroeconomic scenario, including the fiscal position. 


\section{Box 1. Portugal's Stability and Growth Programmes and the excessive deficit procedure}

The main objective of Portugal's successive Stability and Growth Programmes (SGP) has always been to reduce the overall deficit and to sustain a primary surplus over the medium term. For instance, the four programmes submitted between end 1998 and end 2001 laid down a consolidation path which - if adhered to - would by now have achieved budget balance. However, the starting position of each of these programmes turned out to be weaker than originally assumed $^{1}$ (and the speed of consolidation was generally less than planned; as a result, medium-term fiscal targets were never met (Figure 4, upper panel). ${ }^{2}$ One reason for the fiscal slippages against the Stability and Growth Programmes since 2000 has been the systematic overestimation of future economic growth (Figure 4, lower panel). In particular, the 2001-05 downturn turned out to be longer than expected and growth did not resume its earlier mediumterm path of $3 \%$, as assumed in the SGPs. By examining the fiscal positions and the underlying economic assumptions

Figure 4. Portugal's stability and growth programmes
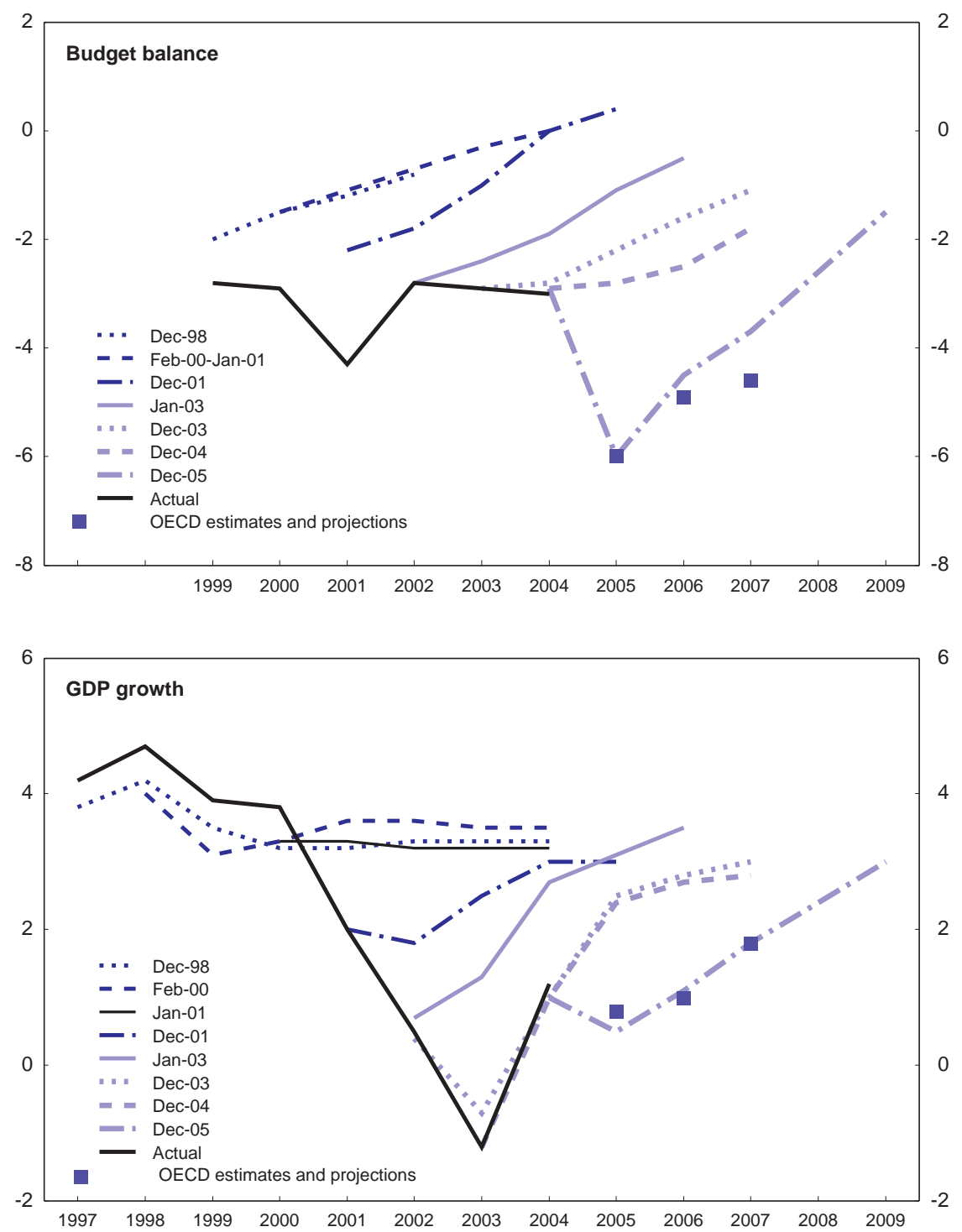

Source: National authorities and OECD, Economic Outlook No. 78. 
in Stability Programmes of EU countries, Milesi-Ferretti et al. (2004) find some evidence that deficits remain higher if governments base their programmes on optimistic economic assumptions. In particular, such programmes bear the risk that governments are less inclined to engage in structural reforms and end up with more difficult fiscal situations than countries with more realistic growth forecasts. As discussed below, the other main reason for fiscal slippages has been the inability to meet the medium-term targets for primary spending, as a percentage of GDP.

Since joining the EMU, Portugal has been submitted twice to the excessive deficit procedure. First, following the rapid deterioration of the fiscal balance in 2001 (to above 4\% of GDP), in October 2002, Portugal was the first EU member country to be submitted to the excessive deficit procedure by the European Commission, a decision confirmed by the Council in November 2002. In response, the Stability and Growth Programme presented by the authorities at endDecember 2002 included a package of measures aimed at containing expenditures on a durable basis. The European Commission and the Council approved these measures as complying with recommendations to take effective action with a view to end the excessive deficit situation. The Stability Programme for 2004-07 was also approved by the European Commission and the Council. In spring 2004, the Commission and the Council decided to abrogate the excessive deficit procedure for Portugal, after concluding that the Portuguese authorities had complied with recommendations to put an end to the excessive deficit situation as rapidly as possible.

On 22 June 2005, when it became clear that the $3 \%$ of GDP deficit ceiling would be missed by a large margin, the Commission initiated the second excessive deficit procedure against Portugal. It issued a recommendation on 20 July 2005, urging Portugal to improve the fiscal position in the short term and correct the excessive deficit by the end of 2008 at the latest, through structural measures. Council recognized the existence of an excessive deficit in September 2005 and confirmed the Commission recommendations. In particular, it confirmed the existence of special circumstances allowing for an extension of the deadline for the correction of the excessive deficit to 2008, considering that too large an effort over a short period could prove economically costly considering Portugal's cyclical weakness. It recommended a reduction of 1.5 percentage points of GDP of the structural deficit in 2006 , followed by a significant decrease of, at least $3 / 4$ percentage points of GDP every year until the excessive deficit is corrected. In addition, the Council asked the Portuguese authorities to ensure that budgetary consolidation to achieve close to balance or a surplus be sustained over the medium term through a reduction in the cyclically-adjusted deficit, net of one-offs and other temporary measures, by at least 0.5 percentage points of GDP per year after the correction of the excessive deficit.

1. The current year was often seen as better than it really was. In addition, methodological changes in fiscal statistics, have contributed to ex-post increases in the deficit.

2. Portugal is of course not the only country in this situation (see OECD Economic Outlook No. 78, Figure 1.10 for a chart of the successive vintages of the Stability Programmes for the Euro area as a whole).

\section{Why was the 2002-2004 deficit reduction short-lived?}

8. The strategy designed in 2002 to rein in the budget deficit and comply with the requirements of the Stability and Growth Pact was two-pronged: achieving the quick results required by the excessive deficit procedure through an increase in the VAT rate, emergency cuts and freezes of spending, and oneoff measures, while preparing and launching necessary in-depth measures to curb expenditure in the medium term. The latter included the closure of some government agencies, steps towards a comprehensive health care reform, launching a public administration reform, the rationalisation of education services, and the approval of a budgetary stability law to better control expenditure. This strategy was appropriate to deal with both the urgency of the situation and the need to address Portugal's weak public finance situation with structural measures that typically take time to implement and to show results.

\section{Implementation of the structural reforms has been patchy and in some cases too slow}

9. The consolidation efforts in 2002-04 were not able to reverse the progression of current primary spending. Cyclically-adjusted current primary spending as a percentage of potential GDP slowed in 2002-04 then accelerated in 2005. Several factors explain the ongoing upward pressure on spending.

- $\quad$ One-off measures, by allowing quick results on the headline deficit, reduced the sense of emergency and commitment to move ahead with painful structural reforms. Although they were 
supposed to be phased-out, they were increased to compensate for the lack of progress on the reform front.

- $\quad$ Keeping emergency measures across the board on wages, automatic career progressions and hiring was politically difficult; and the stance was relaxed at the beginning of 2005 ahead of the parliamentary elections. But public administration reform had lagged and could not generate the savings expected initially: only a few public institutions were closed and the planned reorganisation of central administration stalled; the employment pool created to encourage mobility of civil servants was barely used; the evaluation of civil servants, although legislated in 2004, could not be applied on a systematic basis; the new status for managers, imposing performance requirements and reinforcing managerial autonomy and accountability, and the new career and remuneration system for public servants could not be approved.

- The "big bang" reform in the health sector reform slowed down the expenditure trend, although it did not actually reduce the level of spending in a context of unsatisfied demand for health care. The reform remains nevertheless one of the major achievements of the consolidation efforts. In particular, this reform has allowed a better monitoring of hospital spending (compared with a previous situation where deficits were passively covered ex-post by the general budget). ${ }^{4}$ One of the key differences between this reform and others that were launched at the same time is the comprehensive and radical approach chosen by the authorities. ${ }^{5}$

- The earlier structural reform programme neglected the problem of the general pension system. A reform of this system was initiated in 2001 with the definition of a new benefit formula for disability and old-age pensions; but it foresaw a very long transition period and had only a minor short-term impact on spending. No significant improvement to the financial sustainability of the system was taken in 2002-04. On the contrary, the convergence of minimum pensions to the minimum wage was accelerated, putting additional pressure on spending in 2004-06. ${ }^{6}$ Overall, spending on pensions for both private sector and public sector employees continued to increase rapidly through 2002-05.

- The 2001 Framework Law for the State Budget and the 2002 Budgetary Stability Law, which were major steps forward because they introduced multi-annual spending programmes and tried to strengthen financial coordination between all entities of the general government, were not fully implemented.

Tax rates were lowered too quickly (with a corporate income tax rate cut of 5 percentage points in 2004), once the deficit was below 3\%, although the underlying situation had not improved. A noticeable achievement on the tax front nonetheless has been the increase in the efficiency of tax collection (the impact of which is estimated at about $0.6 \%$ of GDP in 2005).

4. In the past, the annual general budget used to establish a ceiling for total NHS spending, usually on a historical basis. This initial allocation was almost never been respected and supplementary budgets had become the norm. From 1993 to 2002 spending always exceeded the initial budget by an average of $7.5 \%$ (with highest overruns in 1999 and 2002, 10.8\% and 19.6\%).

5. This "Big Bang" health care reform came after a succession of attempts of more gradual reforms launched in the late 1990s and early 2000s that did not survive the political cycle and were never fully implemented.

6. Some $60 \%$ of private pensioners receive only the minimum pension. 
10. The doubling of the deficit from 3\% to close to $6 \%$ between 2004 and 2005 occurred despite some consolidation measures and is to a large degree (about 2 percentage points) explained by the decision to stop the reliance on one-off measure to reduce the deficit, in line with earlier OECD recommendations. It also reflects: $i$ ) lower growth in 2005 than in 2004 (the cyclical impact can be estimated at $1 / 2$ per cent of GDP); and ii) a deterioration of the structural deficit ( $1 / 2$ per cent of GDP). The increase in cyclicallyadjusted primary expenditure was only partly compensated by higher cyclically-adjusted tax revenues, thanks to better tax administration and the decision to increase the VAT rate in July 2005 (after an audit commissioned by the then in-coming government revealed that on current policies the deficit was likely to reach $6.8 \%$ of GDP). ${ }^{7}$

\section{Maximising the chances of success of the new programme}

11. The current consolidation programme is set out in the June 2005 and December 2005 updates of the Stability and Growth programme (see Annex Table). Faced with the urgent need to show some restraint in the short term, as the previous programme, it mixes emergency measures to contain the wage bill in the short term and tax hikes included in the 2005 supplementary budget and the 2006 budget (Box 2) with indepth reforms designed to fix the chronic weaknesses in public spending and ensure fiscal sustainability. A key difference with the 2002-04 policy is the decision to end the reliance on one-off measures. This has only been possible because, under the second excessive deficit procedure it faced, Portugal was given an extended period to get its deficit under 3\% of GDP (Box 1). The target, approved by the European authorities, is to bring the deficit below 3\% of GDP in 2008 (2.6\% of GDP) and reduce it to $1.5 \%$ of GDP in 2009. The planned consolidation efforts, as measured by the reduction of the deficit corrected for the cycle, is on average of about $0.9 \%$ point of potential GDP a year. ${ }^{8}$ However, the macroeconomic scenario underlying this programme could again be on the optimistic side, with growth expected to gain momentum progressively to $3 \%$ in 2009 . With an estimated output gap of $3 \frac{1}{2}$ per cent in 2005 (OECD estimate) and estimated potential output growth slightly below $1 \frac{1}{2}$ per cent, this projection implies that the gap would be closed by 2009.

12. In the short run, an important share of the adjustment comes from the revenue side. Putting more of short-term consolidation efforts on the spending side would have been preferable, but higher taxation appeared as a "necessary evil" given the current Portuguese fiscal situation. Some measures are nevertheless unwelcome. The creation of a new tax bracket with a higher marginal tax rate for high incomes further complicates the tax system and creates additional disincentives to work. In recent years, other EU countries have moved in the opposite direction and reduced the number of tax brackets. In the context of higher tax rates, continued efforts to fight tax evasion will be all the more important for increasing revenue.

7. Cyclically-adjusted primary expenditure increased by $3 / 4$ per cent of GDP in 2005, cyclically-adjusted tax revenues by $0.3 \%$ of GDP.

8. Efforts are larger at the beginning of the period while the consolidation in more growth driven in the lasts years. (The planned reduction in the cyclically-adjusted deficit is of $1 \frac{1}{2}$ per cent of potential GDP in 2006, $3 / 4$ per cent in 2007 and in 2008 and $1 / 2$ per cent in 2009). 


\section{Box 2. Measures announced in 2005 to reduce the deficit in the short term}

\section{Temporary measures to control the wage bill}

Public sector automatic career progressions have been frozen. The increase in public wages has been limited to $1.5 \%$ in 2006 (below the expected inflation rate).

In order to reduce of the number of civil servants, only 1 out of 2 retiring agents will be replaced.

The 2006 budget law also imposes a zero increase in payroll spending by the local authorities.

\section{Raising taxes}

The standard VAT rate was increased from 19 to $21 \%$ in July 2005 , a rate much higher than in neighbouring Spain $(16 \%)$ and among the highest in the EU.

The tax rate on tobacco is increased by 15\% each year between 2006 and 2009.

The tax rate on oil products (ISP) is increased by 7.5 cents per litre in three steps $(2.5$ cents/litre each) at the beginning of 2006, 2007 and 2008. This is on top of the regular increase in line with inflation.

A new tax bracket for the personal income tax has been created. Annual incomes above over 60000 euros face a $42 \%$ marginal tax rate $(40 \%$ before this bracket was created).

The taxation of pension income has been increased and it is planned that it will eventually reach that of wages.

Some special schemes and tax benefits have been cut, although others have been created, for instance on savings for pensions.

\section{Moving forward with in-depth reforms to ensure fiscal sustainability}

13. The direct impact of the 2005 reform measures is expected to represent a net saving of $2.6 \%$ of GDP for the budget by 2009 , while higher taxes bring $2.1 \%$ of extra revenue (Figure 5). ${ }^{9}$ Overall the strategy goes in the right direction. However, the objective of the government to reduce the deficit ratio by around $4 \frac{1}{2}$ percentage points from 2005 to 2009 (which implies an improvement of the cyclically-adjusted primary balance amounting to $3.7 \%$ of potential GDP) appears ambitious given the recent fiscal slippage and the difficulties that Portugal has had in moving forward on structural spending reforms. Implementation thus remains a challenge. There is a risk that some key reforms, on which preparatory work has just started, will lag behind. Where legislation has already been approved, it has to be implemented with no delay. Where the process is just at the stage of intentions, these have to be translated quickly into concrete proposals, and then legislative changes and effective implementation. The structural reforms are concentrated in four areas: public administration; social security; health; and local government and autonomous funds and services spending. ${ }^{10}$

9. This estimate by the authorities only includes measures that are either already legislated or included in the 2006 budget as a multi-annual current expenditure reduction programme.

10. The implementation as of end-2005 is detailed in the December 2005 update of the Stability and Growth Programme. 
Figure 5. Expected impact of the main consolidation measures

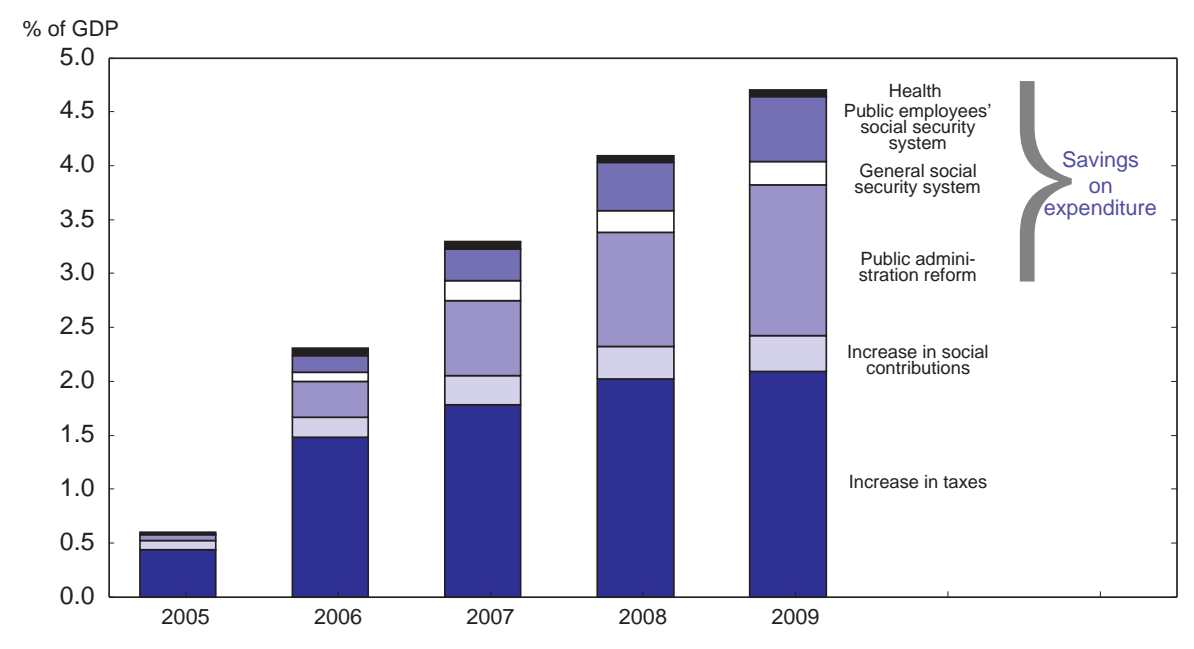

Source: Stability and Growth Programme, December 2005.

\section{Accelerating public administration reform}

14. Public administration reform, which should improve public spending efficiency and effectiveness, plays a central role in the consolidation strategy. More than half of the savings $(1.4 \%$ of GDP by 2009) is expected to result from this reform and significant savings are expected as early as in 2006. It shows some welcome continuity with the previous reform attempt, but it is more ambitious. In particular, in order to accelerate implementation, a broader approach than in the past has been adopted. It involves all the ministries at the same time, which seems more effective than progressing area by area. The reform is organised around five key complementary lines of actions.

- $\quad$ First, a major restructuring of central administration is planned with a new organisation for each ministry expected to be defined by June 2006. The goal is to review and rationalise the functions of the central administration. Some will be left to the private sector, others transferred to regions or decentralised to local governments. A financial controller will be appointed in each ministry to help prepare the budget and control its execution under the double responsibility of the Ministry of Finance and the ministry concerned.

- $\quad$ Second, legal conditions of employment, career and remuneration in the public administration are to be brought in line with private sector rules, with a view to increasing efficiency and promoting mobility of civil servants towards the private sector. Plans to be implemented in early 2007 include in particular streamlining of the number of careers, linking pay and promotion to performance and ensuring suitable rewards for highly qualified positions.

- $\quad$ Third, the employment pool created by the previous administration, but which has only been used marginally, will be reformed. While the restructuring of the central administration is expected to result in closure and merger of services implying important transfers of civil servants to the pool, new rules are being designed to give them incentives for training and for mobility within the public sector or to the private sector. The details of the reform are not ready yet, but possible incentives for mobility could include, for instance, cuts in salary when civil servants remain in the pool for some time. 
- $\quad$ Fourth, the law on public servant evaluation (adopted under the previous administration but only partly implemented) will be reviewed by end 2006 and adapted to specific groups (teachers, doctors, army forces), with a view to generalising the evaluation system to the whole public administration by 2007 .

- $\quad$ Finally, budgeting is also being changed progressively: the 2006 Budget Law contains a multiyear programme for expenditure reduction. A second planned step is to revise and apply fully the 2001 Framework Budget Law (in particular multi-year expenditure ceilings).

\section{Containing spending on social security}

15. Under the current system pressures on pension spending are already high and set to increase at an unsustainable pace. A courageous reform of the generous public sector employee pension system was approved in 2005 (Box 3). This subsystem was closed for new public employees (who will be affiliated to the general system) and will gradually converge to the (less generous) conditions prevailing in the general social security system. Not only should this reform help reducing spending pressure, but it should also facilitate the mobility of public employees to the private sector. A working group has been appointed to design a reform of the general pension system. In the meantime, the focus is on creating incentives to raise the effective age of retirement by imposing strong penalties on early retirement (before the legal age of 65) and suspending or cancelling some early retirement schemes. Progress was also made in slightly increasing the taxation of pensions (which remains well below that of wages). ${ }^{11}$ But this might not be sufficient to reduce incentives to early retirement, even with stronger penalties than in the past. Social security contributions by the self-employed have also been increased. ${ }^{12}$

16. Regarding other areas of social security not linked to pensions, several measures are being adopted to close the generous health subsystem for new public servants and reform the even more generous special public regimes for health care.

\section{Box 3. Public sector pension reform}

CGA (Caixa Geral de Aposentações, the public sector employee pension system) was "closed" as a subsystem at the end of 2005 . There will be no new entrants and this subsystem will gradually converge to the conditions prevailing in the private sector social security system. This implies that:

- $\quad$ All public servants hired after 1 January 2006 will fall within the scope of the general social security system and contributions will be in line with the general system, both for the employee and for employer (whether the latter is classified in the general government sector or not).

- $\quad$ The legal retirement age for public servants will rise in stages from 60 to 65 during the period 2006-15 on the basis of six months a year.

The number of years of service needed to receive a full pension will be extended in stages from 36 to 40 years during the period $2006-13$, on the basis of six months a year.

11. The implicit tax rate on continuing work after the age of 60 was estimated at $14.4 \%$ in 2003 (see Duval, 2003), which is still low compared to OECD countries.

12. The wage reference to determine minimum contributions to social security of the self-employed is raised from 1 to 1.5 minimum wages. This will reduce the bias in favour of this work form. It is a first step forward in the direction of levying social security charges for the self-employed as a proportional share of the net earnings recommended in the 2001 OECD Economic Survey of Portugal. 
- $\quad$ The formula used to calculate retirement pensions for public servants hired before 1993 will be changed to be based on the weighted average of the pension they would have received under the current formula (CGA) and the pension calculated applying the formula of the private sector social security system, with the weighting ascertained by the proportion of the contributory period up to the end of 2005 (CGA) and after 2005 (private sector system).

According to simulations by the authorities this reform should result in annual savings equivalent to $0.4 \%$ of GDP by 2025 and $0.6 \%$ of GDP by 2050, limiting to some extent the increase in the CGA's deficit, although this is still projected to increase from $1.3 \%$ of GDP in 2005 to $3.9 \%$ of GDP in 2050.

\section{Continuing the health care reform.}

17. The authorities are committed to continue the comprehensive reform of the health care sector launched in 2002. In particular, given the overall favourable impact on management, on the evaluation and control culture and on transparency of the transformation of a third of the public hospitals into corporations, all the hospitals including the largest ones will be progressively turned into corporations, by $2009 .{ }^{13}$ At that time, they will all have the same status of public enterprises, EPE (Entidades Públicas Empresarias), which is slightly different from the SA status designed by the previous administration. The main differences are that the capital of EPE hospitals cannot be privatised, they fall under the EPE law of 1999 instead of the commercial code, and their accounts are controlled by a single supervisor appointed by the Ministry of Health. These entities will be able to create enterprises with a majority of public capital for outsourced activities (laboratories, catering, etc.). The rationalisation of the NHS is continuing with the merger and closure of some hospitals. A restructuring of the health care centres is under preparation. Besides, in line with OECD 2004 recommendations, additional steps have been taken to improve the drug reimbursement policy. Measures have also been taken to discourage the excessive use of hospital emergency care units for non-emergency treatments. In the medium term, a complete review of the financing of health care in Portugal is planned that could lead to higher private cost sharing and the development of complementary insurance schemes, which are incipient in Portugal.

\section{Reinforcing control on local government and Autonomous Funds and Services}

18. The Local and Regional Finance Laws are set to be revised, with a view to ensuring that all levels of public administration participate in the efforts of budgetary consolidation by setting systematic rules of fiscal discipline. ${ }^{14}$ In the meantime, instead of applying the existing formulas to calculate transfers to autonomous regions and local governments, these transfers have been frozen in the 2006 Budget at their 2005 value, and the Budget of the State for 2006 also stipulates that the expenditures for the staff of local governments should not exceed their 2005 value. The reporting on the evolution of the financial situation of local governments and the Autonomous Funds and Services (FSA) (incorporated hospitals and other health units, universities and supervision agencies) will be strengthened. Any FSA running a deficit will lose its autonomy as a way to complement the 2001 law that required FSAs to have balanced accounts but did not detail the sanctions.

13. This new status did not go without some problems: there were cases of hidden deficit; some bad managers had to be dismissed. Moreover, human resource management is complicated by the fact that part of the staff is under private contract, part has a public employee status. There was no evidence of cream skimming as was feared when the reform was launched.

14. The details of the reform are due in March 2006. 
ECO/WKP(2006)17

\section{The planned consolidation in comparison}

19. While consolidation is urgent, reducing the budget deficit could have a short-term cost in terms of foregone activity at a time when it is already weak. Indeed, according to some structural macro models, the negative effect of a cut in government spending could be significant. However, this does not rule out the possibility that fiscal consolidation can induce non-Keynesian mechanisms that at least partially offset the immediate negative impact of fiscal consolidation (Box 4). Two channels through which the on-going fiscal consolidation may support growth can be envisaged in Portugal. First, positive effects on growth can come from the supply side: fiscal consolidation should result in lower public wages that, through their links with private sector wage developments, could lead to general wage moderation and improve business profitability and competitiveness. Second, fiscal consolidation may improve the confidence of private agents and thereby boost private spending. It is difficult to assess the potential strength of these channels and also the timing of the various effects. Even if activity could be dampened by consolidation measures in the short run, the effects on growth should be positive over the medium and longer term, at least as compared to the alternative of running unsustainable deficits which would undermine confidence and finally increase the risk premium. But in order to maximize the positive effect of consolidation, it is important that the authorities' commitment to it is fully credible. This underlines the need to launch structural consolidation measures quickly and implement them forcefully.

\section{Box 4. Non-Keynesian effects of fiscal consolidation}

There are two competing views about the effects of fiscal policy on economic activity. According to the Keynesian view output can be increased by fiscal expansion (at least in case of a negative output gap) while fiscal consolidation reduces output. This view is reflected in structural macro models. For Portugal, the IMF model finds that a cut in public spending by $1 \%$ of GDP reduces output in the first year by $0.83 \%$. This is similar to the temporary spending multiplier of the EU QUEST model for Portugal (in the first year 0.58) which finds, however, a much lower (first year) multiplier if the change in spending is perceived as permanent (0.12). Tax multipliers are quite different between these models as according to the IMF model a tax increase by $1 \%$ of GDP reduces output by $0.5 \%$ of GDP while the EU model shows no effect on output.

Proponents of the non-Keynesian view argue that fiscal effects on output are generally very small or have even opposite signs, so that fiscal expansion would not (or only little) increase output while fiscal consolidation would not harm output or even improve it. Non-Keynesian effects of fiscal consolidation could work through various channels: Assuming a fixed money supply, a fiscal consolidation reduces interest rates which crowds in private spending, with the overall effect depending on how much interest rates decline and how interest-sensitive private spending is. In an open economy, the fall in domestic interest rates relative to foreign interest rates leads to capital outflows and - with flexible exchange rates - to a depreciation of the currency (Mundell-Fleming model) which crowds in exports. However, for Portugal all these transmission channels for crowding-in effects appear to be currently not relevant. As a member of EMU short-term interest rates are set by the ECB according to conditions across the entire euro area and long-term interest rates could only be expected to decline if Portugal had a significant risk premium which is currently not the case.

There are two other channels of non-Keynesian effects which are based on the neo-classical theory. First it is suggested that with flexible prices and wages the effect of fiscal policy on output are small (in the extreme case with full flexibility the effects are zero). With fiscal consolidation prices and wages would then fall in response to lower nominal demand and stabilize output and employment. As domestic costs and prices fall relative to those of competitors the real exchange rate would depreciate and crowd in exports and reduce imports, even in a country like Portugal without a domestic currency. The question is, however, how flexible wages and prices are. Portugal's persisting output gap and the fact that despite the large slack the real exchange rate did not depreciate but rather appreciated, indicates that wages and prices may not be flexible enough to immediately compensate the negative demand effects from fiscal consolidation. However, as consolidation measures also include public wage restraint, some positive effects including a real depreciation effect could, perhaps, be expected.

Another channel much emphasized by the neoclassical theory is "Ricardian equivalence". This assumes that households are forward-looking in the sense that they adjust their consumption to their expected long-term (lifetime) income and not to temporary changes of their current income. With fiscal consolidation which reduces current income but not expected lifetime income, as future taxes are expected to be lower, private households will reduce current savings in order to smooth their consumption. (A corollary would be that if the government continues running unsustainable deficits, private households would increase their savings as they would expect higher taxes and lower 
incomes in the future). The Ricardian effect obviously implies that households are not myopic and are also not liquidity constrained. These seem to strong assumptions in the case of Portugal where a relatively large number of low-income households - even if they were not myopic - may be liquidity constrained. This does not mean, however, that no effects could be expected from this channel as consolidation may reduce uncertainty and boost confidence. For example, the OECD estimated from pooled cross-country and time-series data for 16 OECD countries including Portugal a partial but significant private saving offset of fiscal consolidation ( 0.5 in the short-term and 0.7 in the longer term) (OECD (2004) and De Mello et. al (2004)). It also found some co-movement between the decline in Portugal's cyclicallyadjusted fiscal deficit during the consolidation period 1991-1997 and a decline in private saving.

There are a number of studies which examine the fiscal effects by using autoregressive models which do not impose any economic theory but only the order of shocks. ${ }^{1}$ Arcangelis and Lamartina (2003) find Keynesian effects of fiscal shocks for four OECD countries (Germany, France, Italy and the United States) but which have relatively small multipliers and are not long lasting. By contrast, Alesina et al. (2002) find that increases in public wages tend to spill over to private wages so that profits and investment are reduced and they conclude that cuts in public spending, particularly public sector wages and transfers is expansionary. Guidice et. al (2003) also find episodes of expansionary fiscal contractions in the EU countries with more over half of them undertaken without a decline in real interest rates. They suggest that consolidations which began during cyclical weakness and were based on expenditure cuts are more likely to be followed by higher growth.

For Portugal, the IMF (2005) finds with a structural VAR model Keynesian demand effects of government spending while (in contrast to the finding with its above-mentioned macro structural model) changes in taxes had no significant effects. According to the IMF because of the lack of data and the short sample period the results of this analysis should be interpreted with caution and it argues that given the initial poor fiscal conditions with a credible consolidation programme several non-Keynesian effects could partly offset the negative short-term demand effects of lower spending. Tondl (2005) examines the effects of fiscal consolidation for Eastern European countries and a control group of four other countries including Portugal and finds for most countries including Portugal that fiscal consolidation increases growth if this is pursued through cuts in general government current spending while growth is reduced if consolidation is based on raising taxes

1. See Giudice, Turrini and Veld (2003) and Capet (2004) for recent surveys of the literature on non-Keynesian effects of fiscal consolidation.

20. Although this does not minimise the challenge faced by the authorities, experience in other OECD countries are encouraging. Similar and even larger consolidation efforts have been made in the past in a number of OECD countries, including Portugal in the 1980s. And a third of the countries listed in Table 1 also started fiscal consolidation during a downturn with a large output gap, which is the current situation of Portugal. In the twenty cases reported in the table, the pace of consolidation was on average $1 \%$ of GDP per year over 5 years. In 30\% of these consolidation episodes (including Portugal after 2001), the improvements in fiscal balances were fully or mostly achieved by higher revenues. ${ }^{15}$ In half of the episodes, consolidation was mainly achieved by spending cuts which in three countries were so large that taxes could be reduced at the same time. In the cases where consolidation was achieved exclusively or partially by large spending cuts, these affected both current spending and capital spending. In the remaining $20 \%$ of the episodes (including Portugal in the first half of the 1980s), consolidation was achieved more or less equally by a combination of spending cuts and revenue increases. However, the main difficulty has been to maintain fiscal discipline after large cuts in deficits, and six of the nineteen countries listed in table, including Portugal, are faced with deficits currently over 3\% of GDP.

15. In the case of Portugal, after 2001, higher revenues represent mainly 5\% of GDP of exceptional revenues from one-off operations. For instance in 2003 the recording as government revenue of the transfer of unfunded pension obligations from postal services (CTT) to the General Government (0.9\% of GDP) and the sale of non-performing tax and social security claims to a private financial institution at close to $15 \%$ of face value (amounting to $1.4 \%$ of GDP). In 2004, one-off revenues worth almost $2.3 \%$ of GDP were received in exchange for the takeover by the government sector of the pension liabilities of four stateowned enterprises (the banking group Caixa Geral de Depósitos and three smaller enterprises). 
Table 1. Fiscal consolidation episodes in OECD countries

\begin{tabular}{|c|c|c|c|c|c|c|c|c|c|}
\hline & & & & $\begin{array}{l}\text { Change in } \\
\text { primary }\end{array}$ & & ange in $\mathrm{sp}$ & ding $^{2}$ & $\begin{array}{l}\text { Change in } \\
\text { tax and non- }\end{array}$ & $\begin{array}{l}\text { Output gap } \\
\text { at the } \\
\text { beginning of }\end{array}$ \\
\hline & & & & & Total & Current & Net capital & & \\
\hline $\begin{array}{l}\text { Australia } \\
\text { Austria }\end{array}$ & 1993 & - & 1999 & 4.9 & -0.9 & -0.1 & -0.7 & 4.0 & -4.1 \\
\hline Belgium & 1995 & - & 1997 & 3.5 & -2.3 & -1.9 & -0.5 & 0.9 & -0.7 \\
\hline Canada & 1992 & - & 1998 & 4.7 & -0.3 & -0.6 & 0.2 & 3.8 & -0.2 \\
\hline Denmark & 1992 & - & 1999 & 7.9 & -7.0 & -6.6 & -0.4 & 0.1 & -4.1 \\
\hline Finland & 1995 & - & 1999 & 3.0 & -1.7 & -1.5 & -0.2 & 0.6 & -0.1 \\
\hline France & 1992 & - & 2000 & 9.7 & -7.1 & -6.3 & -0.9 & -1.0 & -9.5 \\
\hline Greece & 1993 & - & 1997 & 3.7 & -1.1 & -0.4 & -0.7 & 2.2 & -1.7 \\
\hline Iceland & 1989 & - & 1994 & 12.4 & -3.9 & -3.2 & -0.7 & 8.9 & 1.7 \\
\hline Ireland & 1989 & - & 1992 & 4.4 & -3.7 & -1.6 & -2.0 & 1.3 & 0.7 \\
\hline Italy & 1985 & - & 1989 & 6.6 & -8.2 & -5.9 & -2.4 & -3.1 & -2.7 \\
\hline Netherla & $\begin{array}{l}1989 \\
\text { ds }\end{array}$ & - & 1997 & 9.6 & -2.3 & -0.5 & -1.9 & 7.3 & 0.7 \\
\hline New Zea & $\begin{array}{l}1990 \\
\text { and }\end{array}$ & - & 1996 & 5.6 & -6.1 & -5.3 & -0.8 & -1.6 & 3.2 \\
\hline Norway & 1999 & - & 2003 & 4.6 & -5.6 & -4.0 & -1.7 & -5.1 & 0.1 \\
\hline Portugal & 1992 & - & 1997 & 6.0 & -3.3 & -3.0 & -0.3 & 0.6 & -4.7 \\
\hline & $\begin{array}{l}1980 \\
2001\end{array}$ & - & $\begin{array}{l}1984 \\
2004\end{array}$ & $\begin{array}{l}8.8 \\
3.3\end{array}$ & $\begin{array}{l}-4.4 \\
-0.3\end{array}$ & $\begin{array}{r}-2.9 \\
1.3\end{array}$ & $\begin{array}{l}-1.4 \\
-1.5\end{array}$ & $\begin{array}{l}4.6 \\
2.9\end{array}$ & $\begin{array}{l}1.9 \\
2.4\end{array}$ \\
\hline Spain & 1991 & - & 1997 & 6.0 & -6.4 & -2.4 & -4.0 & -1.3 & 2.9 \\
\hline $\begin{array}{l}\text { Sweden } \\
\text { United K }\end{array}$ & $\begin{array}{l}1993 \\
\text { gdom }\end{array}$ & - & 1998 & 10.7 & -7.4 & -3.9 & -3.5 & 1.0 & -7.6 \\
\hline United S & $\begin{array}{l}1993 \\
\text { tes }\end{array}$ & - & 1999 & 7.5 & -4.8 & -3.3 & -1.5 & 2.6 & -3.3 \\
\hline & 1992 & - & 1998 & 5.1 & -2.6 & -2.3 & -0.3 & 2.3 & -1.7 \\
\hline
\end{tabular}

1. Cyclically-adjusted as $\%$ of potential GDP

2. As $\%$ of potential GDP. Current spending is cyclically-adjusted.

3. As $\%$ of GDP.

4. Deviations of actual GDP from potential GDP as $\%$ of potential GDP

Note: As changes in revenues are expressed as \% of GDP and changes in spending as \% of potential GDP, the difference is not equal to the change in the primary balance which is expressed as \% of potential GDP. Fiscal consolidation episodes are defined as improvements in the cyclically-adjusted primary balance of more than $3 \%$ of GDP in consecutive years.

Source: Calculations based on OECD Economic Outlook, No. 78. 


\section{Further necessary steps towards fiscal sustainability}

21. While the measures taken or under preparation are going in the right direction and, if fully implemented, are likely to succeed in bringing the deficit below $3 \%$, the consolidation programme needs to be complemented by additional reforms so as to ensure medium term fiscal sustainability.

\section{Facing pressure from ageing population}

22. After the 2005 reform of the public sector pension system, a key pending reform is the reform of the pay-as-you go general pension system. A working group has been appointed and is currently analysing alternative policy measures to achieve a comprehensive reform of the pension system. It is important that action in this area is not delayed as the system is under strong pressures arising not only from the ageing population but also from its maturation and the high replacement rates granted to pensioners. According to updated national estimates presented in the 2006 Budget, under unchanged policies, pension expenditure would increase by $4 \%$ of GDP by 2050 (from $7.5 \%$ in 2005 to $11.4 \%$ in 2050) while revenues are expected to increase from $7.8 \%$ of GDP to $8.2 \% .{ }^{16}$ As a result, the system would run a deficit as from 2007 onwards, and the reserve fund would have a zero balance in $2014 .{ }^{17}$

23. Measures taken in 2005 to enhance the sustainability of the pension system include implementing a plan to reduce fraud and contribution evasion and increasing the social contributions of the selfemployed. Other measures include changing the pension benefit formula, which will now take the entire contributory career into account rather than using the best 10 out of the last 15 contributory years as was previously the case. The improvement from this change will be slow to materialise because of grandfather clauses that protect acquired rights. There has also been a change to the pension accrual rate, which now increases progressively over a range of 2 to $2.3 \%$ for those that have contributed for more than 20 years. These changes increase the incentives for older workers to remain in the workforce for longer.

24. There has also been an emphasis on reducing early effective retirement. These efforts should continue but they will only have a limited impact, as the effective retirement age (at 63.7 years old) is already close to the legal age and the second highest in the EU.

25. The Budget 2006 evaluates the impact of three options:

an increase of the legal retirement age to 67 , which would reduce the deficit by $0.2 \%$ of GDP by 2050 ;

- $\quad$ a ceiling on pensions set at 5 times the minimum wage, which would reduce the deficit by $0.1 \%$ of GDP; and

- $\quad$ a faster transition to the new formula adopted in 2002 , which would reduce the deficit by $0.2 \%$ of GDP.

16. The main differences with previous projections are due to the use of more realistic assumptions on productivity, GDP and population growth - although the assumed growth rate of GDP of $2 \%$ year remains on the optimistic side as it assumes average annual labour productivity growth of $2.1 \%$ - as well as the integration of the new public employees to the scheme.

17. This social security reserve fund (Fundo de Estabilização Financeira da Segurança Social, FEFSS) is supposed to receive 2 to 4 percentage points of the employees contribution, as well as any general regime surpluses and capital gains. In 2004 its assets represented 4.3\% of GDP. 
26. More radical changes should be envisaged, such as adjusting replacement rates and/or retirement age for changes in life expectancy of pension cohorts. In addition, some distortions have to be addressed: for instance, under the current system workers are entitled to the minimum pension whether they have worked 30 or 40 years, which reduces incentive to work (in the formal sector) more than 30 years.

27. In addition, financial education and awareness programmes could help the government to explain to the public the need for reform in the general pension system as well as the importance of individual private savings to supplement the public pension. Other OECD countries have used media campaigns for these purposes. For instance, the Slovak government conducted a ten-month-long media campaign beginning in the fall of 2004 to educate the public about the need for pension reform. The Irish Pensions Board has organised pension awareness campaigns over the past several years with the result that over $70 \%$ of the population is now aware of personal retirement savings accounts.

\section{Further steps to control public expenditure and improve efficiency}

28. An important element in successful durable fiscal consolidation in other OECD countries has been improvements in the budget process. Portugal has already taken several important steps including: i) improving the quality of public finance data; ${ }^{18}$ ii) introducing new monthly financial reporting requirements for the health and social security systems, and for all levels of government from 2006 onwards, with penalties for non-compliance; and iii) engaging financial controllers to monitor expenditure and report trends that pose a risk to fiscal consolidation.

29. Another measure taken by many countries to improve the budget process is to introduce or strengthen fiscal rules, although practices differ across countries. Applying and enforcing fiscal frameworks is a difficult task and it is not only a technical issue of fixing appropriate rules but requires a clear political commitment and is therefore also a political-economy issue (see Joumard et al., 2004). In the literature, several (more or less radical) proposals have been made for improving national fiscal policy frameworks. This could, for example, be done by adopting clear long-run fiscal policy objectives and also specifying appropriate procedures when governments violate their own commitments; and by strengthening the role of independent economic advisory councils in the preparation of the budget and the assessment of final outcomes. For example, in case of fiscal slippage the government could be required to give a formal explanation to the parliament or have public hearings with the finance minister and outside experts (CESifo 2005). The Netherlands illustrate a case where multi-year expenditure agreements have had some success, and, although they did not prevent fiscal degradation during the first half of the 2000s, they were instrumental in redressing the fiscal situation quickly (Box 5). In Portugal, multi-annual budgeting was announced in 2001 but has not yet been implemented; moreover, the budgetary law still does not include binding ceilings on expenditure. Progress in this area would help to secure the gains of the ongoing consolidation efforts.

18. An agreement was signed at the start of 2006 between the three Portuguese institutions involved in public accounts statistics, the National Statistical Institute (INE), the Bank of Portugal and the Ministry of Finance. By clarifying responsibilities of each institution and the information exchange requirements, this agreement should result in the reporting of better-quality public finance data. 


\section{Box 5. Multi-year expenditure agreements and consolidation: the Netherlands case}

The Netherlands achieved a major fiscal consolidation in 2004-05. Besides external favourable effects linked to the higher price of natural gas, this process has owed a lot to the medium-term framework adopted by the authorities 10 years before. The framework, introduced in 1994, is based on an agreement between political parties participating in the coalition governments and consists of ceilings on expenditure in each major budget sector (the central government budget; social security; and labour market and health expenditure) established for the duration of the legislature. The ceilings are set in real terms and are adjusted each year for inflation. They are based on cautious macroeconomic projections produced by the independent Netherlands Bureau for Economic Policy Analysis (CPB). Overspending for a specific item in a given sector has to be compensated by lower expenditure on other items within the same sector. Automatic stabilisers are allowed to work fully on the revenue side, except if the deficit comes close to the Maastricht Treaty's 3\% ceiling which would require discretionary fiscal tightening on either the revenue or the expenditure side. Windfalls may be spent only to the extent that they do not result from better-than-expected cyclical conditions and should not be used for new policies. For more details see the 2005 OECD Economic Survey of the Netherlands.

30. In addition, there is a need to develop cost-benefit analysis for public investment on a more systematic basis. This is also essential in the case of public-private partnerships which are increasingly relied upon in Portugal (as in many other EU countries) ${ }^{19}$. Under these schemes, the government can, for instance, instead of buying an asset and operating it, buy the services from a private entity that invests and owns the asset (at least partly and at least during the period of exploitation). It thereby substitutes future payments for these services for current investment costs. This approach has been chosen in the particular cases of several new National Health Service hospitals. If not carefully assessed, these projects can create important contingent liabilities for the government. ${ }^{20}$

\section{Simplifying the tax system and broadening its base}

31. Indirect tax rates are being raised well above neighbouring Spain and most other EU countries and the corporate income tax is still above Eastern European countries that compete fiercely with Portugal for exports and FDI. It would not be wise, however, to lower them before public finances have been put on a sustainable path. On the other hand, there is ample room for simplification of the tax regime which is as important for competitiveness as lowering tax rates and can help improve tax collection efficiency. An informative measure of the complexity of the tax system and its administration is the resource cost of collecting taxes. In international comparison Portugal belongs to the countries with relatively high costs per unit of collected revenues and also has relatively high tax arrears (Table 2). The decline of the average effective tax rate of the VAT relative to the standard rate between 2000 and 2003 might also point to increasing loopholes (Table 3). Tables 2 and 3, however, do not reflect the above-mentioned recent progress on the efficiency of the tax administration.

19. See Koen and van den Noord (2005).

20. See for example Joumard et al. (2004) and Box 2.1 in the OECD Economic Survey of Korea, November 2005 . 
ECO/WKP(2006)17

Table 2. Indicators of administrative costs in tax revenue collection and tax arrears

\begin{tabular}{|c|c|c|c|c|}
\hline & $\begin{array}{c}\text { Administrative costs } \\
\text { as a } \% \text { of collected } \\
\text { revenue }\end{array}$ & $\begin{array}{l}\text { Number of citizens } \\
\text { per full-time staff }\end{array}$ & $\begin{array}{l}\text { Number of labour } \\
\text { force per full-time } \\
\text { staff }\end{array}$ & $\begin{array}{l}\text { Reported gross tax } \\
\text { arrears as a \% of net } \\
\text { tax collections }\end{array}$ \\
\hline & 2002 & 2003 & 2003 & 2002 \\
\hline Australia & 1.19 & 1016 & 512 & 9.3 \\
\hline Austria & 0.72 & 929 & 450 & 9.6 \\
\hline Belgium & 1.00 & 476 & 207 & 14.6 \\
\hline Canada & 1.20 & 810 & 425 & 8.4 \\
\hline Czech Republic & 2.08 & 700 & 351 & 49.7 \\
\hline Denmark & 0.73 & 651 & 348 & 4.9 \\
\hline Finland & $0.67^{1}$ & 820 & 415 & 6.6 \\
\hline France & 1.44 & 788 & 358 & 16.1 \\
\hline Germany & & 665 & 324 & 2.6 \\
\hline Hungary & 1.35 & 768 & 309 & \\
\hline Ireland & $0.95^{1}$ & 625 & 282 & 4.5 \\
\hline Italy & & 1202 & 510 & \\
\hline Japan & 1.62 & 2260 & 1199 & \\
\hline Korea & 0.85 & 2804 & 1359 & 3.0 \\
\hline Netherlands & $1.76^{1}$ & 629 & 320 & \\
\hline New Zealand & 1.17 & 853 & 425 & 4.0 \\
\hline Norway & $0.59^{1}$ & 716 & 374 & 4.0 \\
\hline Poland & 1.32 & 751 & 339 & 8.6 \\
\hline Portugal & 1.68 & 778 & 402 & 43.5 \\
\hline Slovak Republic & 1.46 & 929 & 458 & 39.7 \\
\hline Spain & 0.78 & 1680 & 745 & $5.9(2001)$ \\
\hline Sweden & $0.42^{1}$ & 985 & 494 & 1.9 \\
\hline UK & $1.15^{1,2}$ & $730^{3}$ & 3603 & $17.2^{2}$ \\
\hline USA & $0.52^{1}$ & 2261 & 1445 & 16.1 \\
\hline
\end{tabular}

1. Revenue base includes social contributions.

2. IRD.

3. IRD and C\&E

Source: Tax administration in OECD countries: comparative Information Series (2004), OECD Centre for Tax Policy and Administration.

32. Tax incentives for the business sector complicate tax administration and increase economic costs. Tax administrations have difficulties in verifying if all the deducted items are effectively connected to the firm's activity, and rather than being associated with tax evasion practices. In Portugal large amounts of inadmissible losses are generally presented for tax purposes, reducing fiscal revenues. Bronchi and GomesSantos (2001) pointed to the very small number of corporations paying the bulk of corporation tax receipts and the need to further streamline incentives and deductions in order to broaden the base and to harmonise the corporate income tax rate at a single relatively low rate. ${ }^{21}$ In addition, over the last years there have been constant changes in tax benefits and incentives which have complicated even more their administration and have made long-term decisions by economic agents more difficult. In the 2006 Budget, some action has been taken to simplify the system such as the abolition of some tax benefits and exemptions. However, the creation of a new tax bracket for the personal income tax has gone in the opposite direction. There is a working group on tax simplification but there is no concrete reform plan yet. Progress is needed in this area. Before and after such reform is launched, refraining from revising the tax

21. Currently the statutory corporate tax rate is $25 \%$ and including local taxes $27.5 \%$. 
legislation from one year to the next would make the tax system simpler to deal with and would facilitate long-term decision-making by economic agents.

Table 3. Value-added tax

A. VAT in international comparison, 2003

\begin{tabular}{|c|c|c|c|}
\hline & $\begin{array}{l}\text { Value-added tax } \\
\text { revenue }\end{array}$ & $\begin{array}{l}\text { Standard } \\
\text { rate }^{1}\end{array}$ & Effective VAT rate ${ }^{2}$ \\
\hline & In per cent of GDP & & Per cent \\
\hline Portugal & 8.5 & 19.0 & 11.4 \\
\hline Canada & 3.4 & 7.0 & 4.8 \\
\hline Denmark & 9.7 & 25.0 & 15.1 \\
\hline France & 7.1 & 19.6 & 9.9 \\
\hline Germany & 6.4 & 16.0 & 9.0 \\
\hline Greece & 7.8 & 18.0 & 10.3 \\
\hline Ireland & 7.3 & 21.0 & 13.6 \\
\hline Italy & 6.1 & 20.0 & 8.3 \\
\hline Japan & 2.4 & 5.0 & 3.4 \\
\hline Spain & 6.0 & 16.0 & 9.0 \\
\hline United Kingdom & 7.0 & 17.5 & 8.9 \\
\hline OECD average & 7.1 & 17.7 & 10.1 \\
\hline EU15 average & 7.5 & 19.6 & 11.1 \\
\hline
\end{tabular}

\section{B. Effective VAT in per cent of standard rate}

\begin{tabular}{|c|c|c|c|c|}
\hline & 1990 & 1995 & 2000 & 2003 \\
\hline Portugal & 46.0 & 59.0 & 66.5 & 59.7 \\
\hline Canada & 46.2 & 44.4 & 49.2 & 68.1 \\
\hline Denmark & 53.0 & 57.2 & 58.3 & 60.3 \\
\hline France & 61.1 & 50.4 & 53.0 & 50.7 \\
\hline Germany & 63.8 & 63.4 & 59.0 & 56.3 \\
\hline Greece & 50.6 & 48.7 & 53.0 & 57.3 \\
\hline Ireland & 43.6 & 51.9 & 58.2 & 64.6 \\
\hline Italy & 41.7 & 42.2 & 42.7 & 41.4 \\
\hline Japan & 68.2 & 73.0 & 73.7 & 67.5 \\
\hline Spain & 60.1 & 44.8 & 49.7 & 56.5 \\
\hline United Kingdom & 53.1 & 50.6 & 50.1 & 50.8 \\
\hline Average of above countries & 53.4 & 53.2 & 55.8 & 57.6 \\
\hline
\end{tabular}

1. Position as of 1 January 2003. In January 2006, the standard rate was $21 \%$ in Portugal and $19 \%$ in Greece (the other rates had not changed).

2. Effective VAT rate is VAT revenue divided by base (i.e consumption exclusive of VAT).

Source: OECD, Revenue Statistics and Consumption Tax Trends. 


\section{Bibliography}

Alesina, A., S. Ardagna, R. Perotti, F. Schiantarelli (2002), "Fiscal Policy, Profits and Investment," American Economic Review, Vol. 92 (3).

Arcangelis G. and S. Lamartina (2003), "Identifying fiscal shocks and policy regimes in OECD countries," Working Paper Series 281, European Central Bank.

Bronchi C. and J. Gomes-Santos (2001), "Reforming the tax system in Portugal," OECD Economics Department Working Paper, No. 302, OECD, Paris, July.

Capet S. (2004), “The Efficiency of Fiscal Policies: a Survey of the Literature," CEPII, Working Paper No. $2004-11$.

CESifo (2005), European Economic Advisory Group (EEAG) at CESifo, "Report on the European Economy 2005", Appendix 3 to Chapter 1 "Is the Stability and Growth Pact dead?"

De Mello, P. M. Kongsrud and R. Price, (2004), "Saving behaviour and the effectiveness of fiscal policy," OECD Economics Department Working Paper, No. 397, OECD, Paris, July.

Duval R. (2003) "The retirement effects of old-age pension systems and other social transfer programmes in OECD countries" OECD Economic Department Working Paper, No. 370, OECD, Paris, November.

Giudice G., A. Turrini and J. Veld (2003) "Can fiscal consolidations be expansionary in the EU? Ex-post evidence and ex-ante analysis," European Economy Economic papers, No. 195, December 2003, European Commission. Brussels.

Guichard (2004), "The reform of the health care system in Portugal," OECD Economics Department Working Paper, No. 405, OECD, Paris.

Guichard (2006) "Improving the performance of Portugal's education system," OECD Economics Department Working Paper (forthcoming).

IMF (2005) Portugal: Selected Issues IMF Country Report No. 05/376.

Joumard, I., P.M. Kongsrud, Y.Nam, and R.Price (2004), "Enhancing the Effectiveness of Public Spending: Experience in OECD Countries", OECD Economics Department Working Paper, No. 380, OECD, Paris.

Koen V. and P. van den Noord. (2005) "Fiscal gimmickry in Europe: One-off measures and creative accounting", OECD Economics Department Working Paper, No. 417 OECD, Paris.

Milesi-Ferretti et al (2004), "Fiscal Adjustment in EU Countries: a Balance Sheet Approach", MilesiFerretti, G.M. and K. Moriyama, in: Public Debt, Banca d'Italia, Research Department Public Finance Workshop, 2004.

Ministry of Finance (2005), The Portuguese Economy.

OECD (2004), “Economic Outlook”, 2004/2, No.76, Paris.

OECD (2005), “Economic Survey of Korea”, November.

Tondl G. (2004), "Macroeconomic Effects of Fiscal Policies in the Acceding Countries" mimeo. 


\section{Annex}

\section{Background Information}

Annex Table A.1. - Status of the main budgetary consolidation measures

\begin{tabular}{|c|c|c|c|}
\hline & $\begin{array}{l}\text { Impact } \\
\text { from }\end{array}$ & Legislation stage* $^{*}$ & Implementation progress \\
\hline REVENUE & & & \\
\hline $\begin{array}{l}\text { Taxes on income and wealth } \\
\text { i) Measures tackling tax evasion and improving the } \\
\text { efficiency of Tax Administration } \\
\text { ii) Tax benefits } \\
\text { Reduction in IRS specific deductions for the highest } \\
\text { pensions income } \\
\text { Tax breaks for restructuring companies (DL 404/90) } \\
\text { Imposition of constraints within the scope of } \\
\text { article } 69 \text { of IRC Code } \\
\text { Shortening of discretionary decision on clause } 4 \text { of } \\
\text { article } 33-A \text { of the tax benefit statute for offshore } \\
\text { zones } \\
\text { iii) Creation of an additional IRS tax bracket with a } \\
\text { marginal rate of } 42 \% \text { to be applied to annual } \\
\text { incomes above } 60 \text { thousand euros }\end{array}$ & $\begin{array}{l}2005 \\
2006\end{array}$ & $\begin{array}{l}\text { Several administrative } \\
\text { measures. } \\
\text { Article } 53 .^{\circ} \text { of CIRS } \\
\text { (art. } 43 \text { of } 60 \mathrm{~A} / 2005 \text { of } \\
30 \text { December - Budget } \\
2006 \text { - Chapter IV). } \\
\text { The Law was abrogated } \\
\text { Law } 50 / 2005 \text { of } 30 \text { August }_{\text {and Resolution }} \\
\text { (despacho) n. }{ }^{\circ} 79 / 2005- \\
\text { XVII of } 15 \text { April } \\
\text { Article } 33^{\circ} \text {-A (art. }{ }^{\circ} 55^{\circ} \text { of } \\
\text { Law } 60-A / 2005 \text { of }_{30 \text { December - } 2006 \text { - }} \\
\text { Chapter X). } \\
\text { Article } 68 . \text { of CIRC } \\
\text { (art. } 43 \text { of Law } 60-A / 2005 \\
\text { of } 30 \text { December - Budget } \\
2006 \text { - Chapter IV). }\end{array}$ & $\begin{array}{l}\text { Implemented } \\
\text { Implemented } \\
\text { Implemented }\end{array}$ \\
\hline $\begin{array}{l}\text { VAT } \\
\text { i) Tackling tax evasion } \\
\text { ii) Increasing standard rate from } 19 \text { to } 21 \% \\
\text { iii) Tax benefits } \\
\text { Revision of the VAT exempt regime in the case of } \\
\text { restructuring financial holdings } \\
\text { Revision the rules for partial deduction of VAT }\end{array}$ & $\begin{array}{l}2005 \\
2005 \\
2005\end{array}$ & $\begin{array}{l}\text { Several administrative } \\
\text { measures: i) Article } 45 . \\
\text { No. } 3 \text { of Law } 60-A / 2005 \text { of } \\
30 \text { December - } \\
\text { Chapter VII Budget } 2006 \text { - } \\
\text { Legislative authorization; } \\
\text { ii) special provisions in } \\
\text { the VAT rules for } \\
\text { recyclable waste sector. } \\
\text { Law } 39 / 2005 \text { of } 24 \text { June } \\
\text { Several administrative } \\
\text { measures. } \\
\text { Several administrative } \\
\text { measures. }\end{array}$ & $\begin{array}{l}\text { implemented } \\
\text { implemented }\end{array}$ \\
\hline
\end{tabular}




\begin{tabular}{|c|c|c|c|}
\hline $\begin{array}{l}\text { An increase in ISP of } 7.5 \text { cents per liter to come into } \\
\text { effect in three steps ( } € 0.025 / \text { litre each) at the } \\
\text { beginning of } 2006,2007 \text { and } 2008\end{array}$ & 2006 & $\begin{array}{l}\text { Article } 49 \text { of Special } \\
\text { Consumption Tax Code } \\
\text { (art. } 49^{\circ} \text { of Law } \\
60 A / 2005 \text { of } \\
30 \text { December - Budget } \\
2006 \text { - Chapter VII). }\end{array}$ & $\begin{array}{l}\text { Implemented (Regulation } \\
\text { (portaria) } 75-\mathrm{A} / 2006 \\
18 \text { January } 2006 .\end{array}$ \\
\hline $\begin{array}{l}\text { Tax on tobacco } \\
\text { A nominal annual } 15 \% \text { rise in the tax levied per } \\
\text { packet of cigarettes for each year between } 2006 \text { and } \\
2009\end{array}$ & 2006 & $\begin{array}{l}\text { Article } 83 . \text { of } \\
\text { Consumption Special Tax } \\
\text { Code (art. }{ }^{\circ} 48 \text { of } 60- \\
\text { A/2005 of } 30 \text { December - } \\
\text { Budget } 2006- \\
\text { Chapter VII). }\end{array}$ & Implemented. \\
\hline $\begin{array}{l}\text { Social security contributions } \\
\text { i) A rise in the wage reference to determine minimum } \\
\text { contributions to social security of the self-employed } \\
\text { from } 1 \text { to } 1.5 \text { minimum wages. } \\
\text { ii) Measures to tackle evasion and fraud }\end{array}$ & 2005 & $\begin{array}{l}\text { Decree Law 119/2005, } \\
22 \text { July. }\end{array}$ & $\begin{array}{l}\text { In place since July } 2005 . \\
\text { Legislation on fraud and } \\
\text { penalties revised, change } \\
\text { in contributions rate and } \\
\text { regularization of debts to } \\
\text { occur in } 2006 \text {. }\end{array}$ \\
\hline \multicolumn{4}{|l|}{ EXPENDITURE } \\
\hline $\begin{array}{l}\text { Control of social security expenditure } \\
\text { Private sector } \\
\text { Unemployment benefits } \\
\text { Early retirement }\end{array}$ & $\begin{array}{l}2006 \\
2006\end{array}$ & $\begin{array}{l}\text { New framework for } \\
\text { unemployment benefits. } \\
\text { Decree Law n. }{ }^{\circ} \\
125 / 2005,3 \text { August, } \\
\text { suspending and } \\
\text { abrogating some of the } \\
\text { early retirement schemes. } \\
\text { Law No. }{ }^{\circ} 60 / 2005 \text {, } \\
29 \text { December, establishes } \\
\text { new rules for public } \\
\text { service retirement. } \\
\text { Special regimes of } \\
\text { retirement within public } \\
\text { administration were also } \\
\text { revised to assure } \\
\text { convergence with the } \\
\text { general security system } \\
\text { by the Decree law } n^{\circ} \\
229 / 2005,29 \text { December. } \\
\text { The employers social } \\
\text { contribution to CGA was } \\
\text { increased to } 13 \% \text {. Law } \\
60-A / 2005,30 \text { December- } \\
\text { Budget } 2006 \text {. }\end{array}$ & $\begin{array}{l}\text { To be reviewed until the } \\
\text { end of } 2006 \text {. }\end{array}$ \\
\hline Savings on medicine subsidies & 2005 & & \\
\hline $\begin{array}{l}\text { Wage moderation in the public service } \\
\text { i) Wage scale update of } 1.5 \% \text { per year } \\
\text { ii) Reduction in the wage drift (i.e. the average wage } \\
\text { increase beyond the wage scale update), through: }\end{array}$ & 2006 & $\begin{array}{l}1.5 \% \text { in } 2006 \\
\text { Automatic progression in } \\
\text { careers freeze until } \\
\text { December } 2006 \\
\text { (Law } 43 / 2005 \\
29 \text { August } 2005 \text { ). }\end{array}$ & \\
\hline New public service wages and careers structure & 2007 & & Preparatory works in \\
\hline
\end{tabular}


from 1 January 2007 onwards

Freeze on automatic career progressions until New career and remuneration system comes into force

Constraints on promotions until New career and remuneration system comes into force

Slower growth of public servants' imputed social contributions

Effective Public servants placement on Surplus Staff Exchange

Revision of the rules on extra-time compensation for doctors

Elimination of compensation for students on education trainee work

Reduction in the number of public servants (relative to a $0 \%$ change benchmark), and better human resources management

i) Partial replacement of public servants who retire

ii) Revision on teaching profession career code, to decrease the number of schoolteachers with reduced or zero classroom hours

iii) Workers who move from the Public Employment Pool to the private sector

iv) Limitation on admission of new public servants in regional and local government progress. Target date December 2006.

Implemented see ii)

Implemented see ii)

The special regimes for military and police forces and judicial bodies revised to assure convergence with general rules for public servants medical assistance.

Decree Law No. ${ }^{\circ}$ 67/2005

23 September;

$n^{\circ} 158 / 2005$

20 September;

2006

$n^{\circ} 212 / 20059$ December.

2006

2006

2005

Art. 16 of the 2006 budget Law. Public servants hiring is subject to the Minister of finance authorization. The rule is to hire one person for two leaving public administration (retirement or any other reason).

Art. 17 of the 2006 budget Law. The compensation of employees in local governments should be kept at the 2005 level. 


\section{WORKING PAPERS}

The full series of Economics Department Working Papers can be consulted at www.oecd.org/eco/Working_Papers/

488. Are House Prices Nearing a Peak? A Probit Analysis for 17 OECD Countries (June 2006) Paul van den Noord

487. Maintaining Switzerland's Top Innovation Capacity (June 2006) Florence Jaumotte

486. Employment Patterns in OECD Countries: Reassessing the Role of Policies and Institutions (June 2006) Andrea Bassanini and Romain Duval

485. Brazil's Fiscal Stance During 1995-2005: The Effect of Indebtedness on Fiscal Policy Over the Business Cycle

(May 2006) Luiz de Mello and Diego Moccero

484. Realising the Oil Supply Potential of the CIS: The Impact of Institutions and Policies (May 2006) Rudiger Ahrend and William Tompson

483. Summary of a workshop on global convergence scenarios: structural and policy issues (May 2006) Nick Vanston

482. Revised OECD methods for supply-side and medium-term assessment: a capital services approach (Forthcoming in June) Pierre-Olivier Beffy, Patrice Ollivaud, Pete Richardson and Frank Sédillot

481. Balancing health care quality and cost containment: the case of Norway (February 2006) Alexandra Bibbee and Flavio Padrini

480. The ageing challenge in Norway: ensuring a sustainable pension and welfare system (February 2006) Benoît Bellone and Alexandra Bibbee

479. Strengthening innovation in the Netherlands: Making better use of knowledge creation in innovation activities (February 2006) David Carey, Ekkehard Ernst, Rebecca Oyomopito and Jelte Theisens

478. How to sustain growth in a resource based economy? The main concepts and their application to the Russian case

(February 2006) Rudiger Ahrend

477. Projecting OECD health and long-term care expenditures: What are the main drivers? (February 2006)

476. Alternative measures of well-being (January 2006) Romina Boarini, Åsa Johansson and Marco Mira D'Ercole

475. Recent house price developments: the role of fundamentals (January 2006) Nathalie Girouard, Mike Kennedy, Paul van den Noord and Christophe André

474. Reforming federal fiscal relations in Austria

(January 2006) Andrès Fuentes, Eckhard Wurzel and Andreas Wörgötter

473. Product market competition and economic performance in France

Concurrence sur les marchés de produits et performance économique en France

(January 2006) Jens Høj and Michael Wise 


\section{ECO/WKP(2006)17}

472. Product market reforms and employment in OECD countries (December 2005) Giuseppe Nicoletti and Stefano Scarpetta

471. Fast-falling barriers and growing concentration: the emergence of a private economy in China (December 2005) Sean Dougherty and Richard Herd

470. Sustaining high growth through innovation: reforming the $R \& D$ and education systems in Korea (December 2005) Yongchun Baek and Randall Jones

469. The labour market in Korea: enhancing flexibility and raising participation (December 2005) Randall Jones

468. Getting the most out of public-sector decentralization in Korea (December 2005) Randall Jones and Tadashi Yokoyama

467. Coping with the inevitable adjustment in the US current account (December 2005) Peter Jarrett

466. Is there a case for sophisticated balanced-budget rules? (December 2005) Antonio Fatás

465. Fiscal rules for sub-central governments design and impact (December 2005) Douglas Sutherland, Robert Price and Isabelle Joumard

464. Assessing the robustness of demographic projections in OECD countries (December 2005) Frédéric Gonand

463. The Benefits of Liberalising Product Markets and Reducing Barriers to International Trade and Investment in the OECD

(December 2005)

462. Fiscal relations across levels of government in the United States (November 2005) Thomas Laubach

461. Assessing the value of indicators of underlying inflation for monetary policy (November 2005) Pietro Catte and Torsten Sløk.

460. Regulation and economic performance: product market reforms and productivity in the OECD (November 2005) Giuseppe Nicoletti and Stefano Scarpetta.

459. Innovation in the Business Sector (November 2005) Florence Jaumotte and Nigel Pain

458. From Innovation Development to Implementation: Evidence from the Community Innovation Survey (November 2005) Florence Jaumotte and Nigel Pain

457. From Ideas to Development: the Determination of $R \& D$ and Patenting (November 2005) Florence Jaumotte and Nigel Pain

456. An Overview of Public Policies to Support Innovation (November 2005) Florence Jaumotte and Nigel Pain

455. Strengthening Regulation in Chile: The Case of Network Industries (November 2005) Alexander Galetovic and Luiz de Mello 